\title{
4. Unflowing Pasts, Lost Springs and Watery Mysteries in Eastern Polynesia
}

\section{ALEXANDER MAWYER}

\section{Sweet and Bitter Waters}

With attention to both local and extra-local processes of construal of the cultural place and significance of water on the landscape in French Polynesia's Gambier Islands, I query the sometimes uncertain character and cloudy nature of water in this part of the Pacific. The molecular constancy of the substance notwithstanding, it seems that water is not always what it was or even where it was in recent pasts. For instance, in Eastern Polynesia the seemingly straightforward and highly culturally salient contrast in the binary opposition between tai and vai, salt and fresh waters, may displace the need to address the current complexity of the situation in which fresh waters on Pacific islands now stand. ${ }^{1}$ Famously binary cultural logics can mask significant cultural ambiguities and practical uncertainties (Feinberg 1980; Mawyer 2014). Similarly, an enduring and valuable focus on the immensely profound place of Ocean for these 'peoples of the sea' (Buck 1938b) and of 'salt' (Hau'ofa 1998),

1 In spoken Mangarevan, the everyday distinction is often between vai and vai kava, sweet as opposed to salty or bitter waters. 
and for the social and cultural histories of these islands, their original settlements and subsequent inter-island spheres of transaction and exchange, may have obscured the anthropological need to examine fresh waters in Oceanic contexts.

Helmreich (2011: 18) sources an early commentary on anthropology's heightened and focal fascination with salt waters to Malinowski, who for his part characterises the ocean as wild, unruly, fundamentally dangerous and requiring magnificent cultural affordances, but land as domesticated and relatively tamed (Malinowski 1931: 634-5, 1992: 30). Works like Sir Peter Buck's Vikings of the Sunrise (1938a) echo such perceptions, as does his Ethnology of Mangareva (1938b), where fresh waters, including important springs, receive scant attention. Although both domains of primal waters deserve reconsideration in the context of the broad revaluation of the place and status of liquid nature in contemporary anthropology (Strang 2004; Helmreich 2011, 2014; Wagner 2013), the status of fresh waters in Oceania particularly calls for refreshed attention given the possibility that in some Pacific places, such as Mangareva in the Gambier Islands, the apparent transparency of this everyday substance may draw attention away from significant anthropological murk around contemporary experience.

With reference to the Gambier, this chapter inquires into the significance of known springs, intimately felt to be important, that no longer bubble forth, much less flow downslope to cultivated lands or the ocean. What might be made of lost waters whose spectral presence in chants or legends can produce a sense of the uncanny when compared to otherwise expert knowledge of nuku and kaiga, maternal lands and lands held as property? Similarly, how might dry watercourses, unswampy swamps, ruins of traditional irrigation systems and other sorts of complicated objects on the contemporary landscape further support a reinterpretation of water in the Gambier Islands, in a region imaginatively dominated by the ocean, and where river courses may be short, not particularly voluminous and may even be seasonal? Even moderate waters can hold a significant place on the landscape, and blockages or discontinuities in flowing water can reveal much about local understandings of past and present island natures and local culture.

$V a i$, fresh water, in static, non-mobile forms, complements the riverine character of the chapters in this collection that promote attention to flow and flux and the generally moving and transporting character 
of gushing waters along gravity's gradient to the sea. There are, of course, locally important rivers in Eastern Polynesia such as Papeno'o on Tahiti, Taipivai on Nuku Hiva, or Wailua on Kauai. Even in the small yet high Gambier Islands, the possibly misleading translation 'river' for the word tairuavai - which I would gloss as 'watercourse' — can be found in the published lexicon (Janeau 1908; Rensch 1991; Tregear 2009). However, I draw attention to vai not only in its coursing flow but also in its form of standing waters, waters gently welling from the islands' freshwater lens as puna, freshwater springs or as seepages at the vertex of some ridgeline's watershed. The foundational role of springs as sources of standing fresh water in Eastern Polynesia has been commented on in numerous contexts, including in myth, cultural metaphor, studies of socio-spatial organisation, and recently as part of the linguistic and anthropological turn to the concept of landscape (Burenhult and Levinson 2008; Cablitz 2008; Levinson 2008). However, passing time has eroded or otherwise obscured some of the cultural practices and understandings on which many existing comments on Polynesian springs rest. Moreover, the basic presence or place of springs and other waters on the landscape of these islands can be far from stable over historical time.

Over the course of my fieldwork, I heard numerous youths in a variety of contexts assert that kupuna ('elders' or 'grandparents') are guardedly jealous of their knowledge. This distrust of the older generation's willingness to share atoga tika ('true histories') was commonplace and, as I have noted elsewhere (Mawyer 2008), is among the most significant dimensions of Mangarevans' reflections on cultural transmission in the early 2000s. For instance, one afternoon, after school had finished, I was chatting with some young teens playing with a soccer ball (keuai popo). This was in front of the 'are ao (town hall) at the very centre of Rikitea, Mangareva's primary village. I had been on Mangareva for some time and my general interests were well known. So, attempting to impress me with their knowledge of things traditional, these boys began to recount the story of the legendary Noe's funeral canoe, which had ploughed into the mountain above Rikitea, creating a channel for divine, life-giving water to flow down to the lands around which the village would be founded, and creating an opening into the sea (Buck 1938b: 22). As it turned out, not one of the five boys playing could remember details of this story. Indeed, the punchline of the story, that the primary watercourse for the island's main village resulted from the piercing of the land by Noe's canoe and the release of flowing water, was completely unknown to them. 
That a legendary canoe had pierced the ridgeline above and the name of the hero (though not the fact that he was dead at the time) was what they knew. That there was a connection between that cleft in the ridge and the watercourse at the centre of the village, which was previously sometimes called by his name, was unknown to them. Moreover, sharing what I knew about this, and describing how I knew it, led to an interesting moment when several of the youths stopped a couple of their adult uncles passing along the ara nui ('primary road') on their way home and, after asking them to confirm the basic story, pleaded (in French): 'Why don't we know this story?' To which the two more senior men responded with a worried, uncertain shrug.

The fact that youths, when accidentally confronted with evidence of slippages in the facts of intergenerational transmission of cultural knowledge, experience more or less passing, visceral and certainly meaningful moments of anxiety was hardly surprising, though I was struck then and now by their projection of responsibility onto more senior generations. In an intriguing moment of parallelism, when I was working some months later with a group of very senior experts on place names embedded in old texts, I did find myself surprised. In a previous meeting, as part of a locally initiated group compiling a new dictionary, we had worked through a list of place names, including those of a number of springs, compiled by Ioani Mamatui, a well-remembered expert of the previous generation, and one of Peter Buck's primary informants at the time of the Bishop Museum expedition in 1934. Daniel Teakarotu, one of the island's largest landholders and agriculturalists and the grandson of Karara, another of Buck's primary informants and a recognised poukapa (cultural expert), had set out to find several of the springs that featured in important myths or historical practices associated with the island's 'akariki ('chiefs'). ${ }^{2}$ The fact that a week later he was not able to say exactly where these springs were-that they eluded him or had literally disappeared from the landscape - was a source of powerful astonishment to the group, at least equal to that experienced by the soccer-playing youths. In more or less the same words, I heard the men of this working group ask why they did not know where the specifically chiefly waters known to be associated with nameable lands were, and how they could have lost this knowledge.

2 'Special things associated with the ruler were his house, assembly place, and well or spring of fresh water ... a drinking pool or spring (vai) was reserved for the king and had a special name. The king, Ohokehu, had a pool at Vaitina named Vaihi with a special keeper in charge' (Buck 1938b: 153). 
That evening in 2003, and again six years later in the summer of 2009, we discussed several possibilities. Perhaps the successful plantations of hardy pines established by the territory's agricultural service since the 1960s, which have utterly transformed the face of the islands (Mawyer 2015), are responsible for disrupting the subterranean shape of the freshwater lens. Or perhaps it was the massive erosion, both visible and regularly discussed in everyday life, caused by the wanderings and ruminations of the goats introduced in the nineteenth century, and the cows introduced in the twentieth century, on the upland slopes of all the archipelago's high islands. Or perhaps it was an increased human drain on the aquifer by mechanisms not entirely easy to calculate. Most worrisome, as suggested by the most soulful of the three senior speakers I was working with that night, perhaps the water could no longer be found because they had forgotten to honour the places in which it flowed, pointing also to the sacredness of the chiefly residential context of the sites of the former springs.

On reflection, it is not surprising that youths in the Gambier Islands or across Polynesia are anxious about cultural loss, but it is perhaps very surprising that kupuna and koumotua (honoured senior persons), with respected expertise and familiarity with linguistic and cultural shifts over their lifetimes, can be blindsided so profoundly by the common fact of water flowing or not flowing across the landscape. Such anxieties reveal that sweet waters (vai) can sometimes be bitter (vai kava), unusable like the sea, disrupting local sureties and senses of place.

In the sections that follow, I engage with the culturing of water on the landscape and identify some of the ways in which vai, as flowing or unflowing water, proves to be a complicated object of anthropological analysis on one hand, and of contemporary Mangarevan cultural experience on the other. Next I consider an anthropological anxiety present in scholarly texts regarding the sustainability of freshwater supplies in these islands. I then survey the rich and extended freshwater vocabulary of Mangarevan and related Polynesian languages, before returning to the question of Mangarevan seniors' reflections on lost springs, blocked flows and the ways in which waters provide or do not provide a living relation to the past. I conclude with a discussion of how water in Mangarevan experience relates to water as an object of anthropological inquiry. 


\section{Backgrounds and Foreshores}

In French Polynesia's Gambier Islands, contemporary Mangarevans have a disconcerting relationship with their island environments, wild and domesticated alike, as I have begun to describe elsewhere (Mawyer 2015). The islands rise from the oceanic deeps, $1,700 \mathrm{~km}$ southeast of the political and social centre of French Polynesia on the island of Tahiti. Eight primary high islands, amounting to $27 \mathrm{~km}^{2}$ of land surface, and a vibrant coral lagoon are inscribed in a barrier reef of around $90 \mathrm{~km}$ in circumference. The non-trivially varied micro-ecologies today include high grassy peaks, upland pine forests, traditional and neo-traditional downslope forests and highly varied near-shore house gardens and plantations with introduced, endemic and some other remaining indigenous flora in regular cultivation. Temporary watercourses can be found in most of the valleys. Remains of past irrigation stoneworks and terracing can also be found in many of the islands' bays. Traditional village sites tend to be associated with 'swampier' but cultivable areas in the foreshores of coastal bays, though today most of these sites are abandoned, having experienced constantly decreasing occupation since the mid-nineteenth century. French nuclear testing on nearby Mururoa and Fangataufa in the 1960s and 1970s led to a concentration of the remaining Mangarevan population in the main village of Rikitea, with a small number of families maintaining home sites in Taku and a few other locations (see Figure 4.1). Sand islands (motu) on the fringing reef are home to well-established though somewhat under-maintained coconut plantations, but today these islands are more likely to serve as the sites for weekend family vacations or 'get-aways' than for sustained occupation. Prior to contact with Europeans, all the islands of the chain were densely occupied, as were the sandy barrier islands that encircle the lagoon and the outlying atoll of Temoe to the east of the group. Only the three islands of Aukena, Akamaru and Mangareva were inhabited between 1999 and 2009, the years between my first and last visit. Other islands in the group were home to a few families until the 1960s, while Aukena and Akamaru themselves are home to only a few families, with temporary stays by labourers working on adjacent pearl farms. 


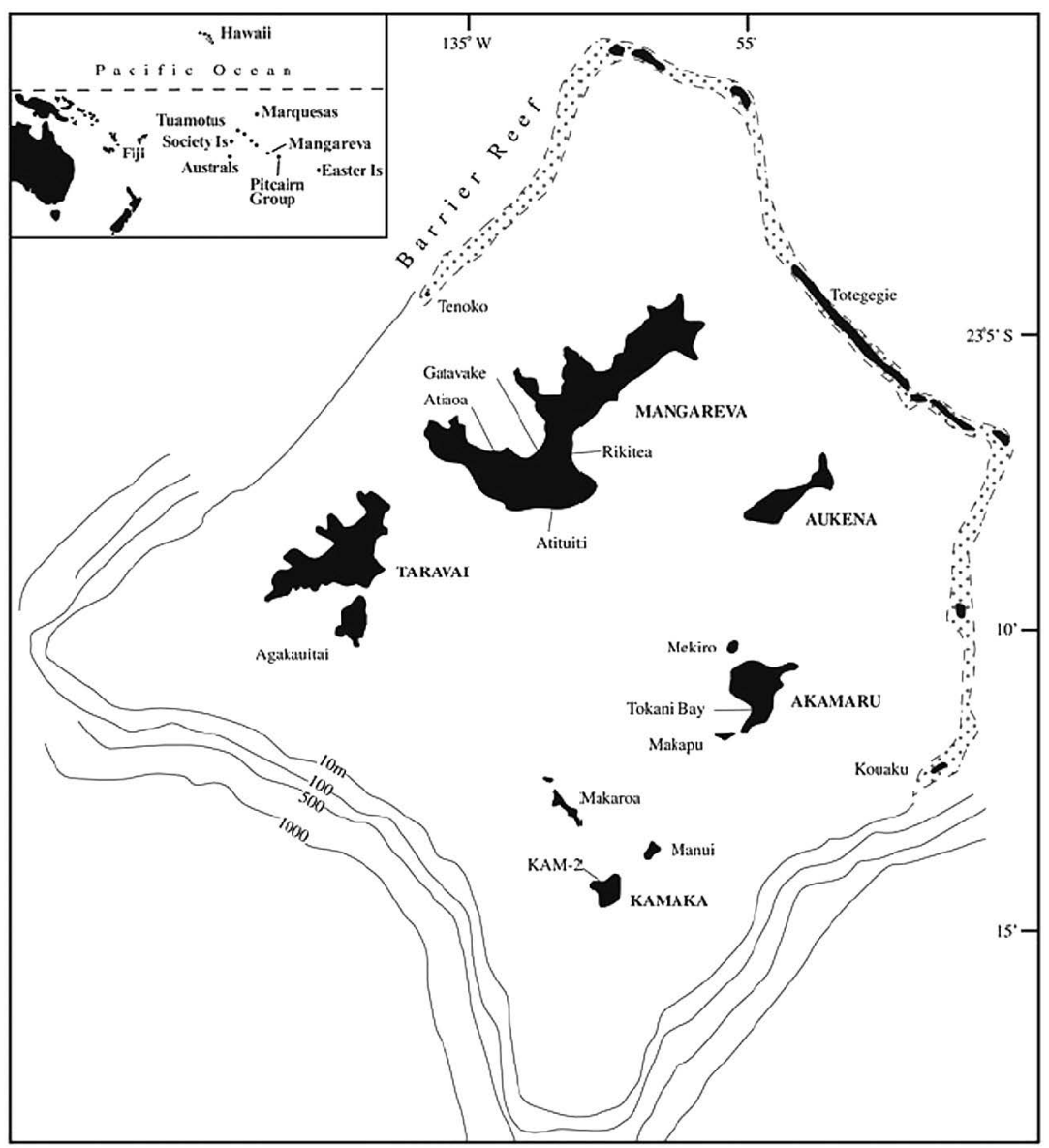

Figure 4.1 Map of the Gambier Islands in French Polynesia.

Source: Adapted from Anderson et al. (2003: 120).

In recent years, the Gambier's growing population has been reclaiming formerly inhabited spaces, yielding encounters that can be both surprising and disconcerting in their historical inflections as families clear land for the first time in many decades, or even in a century. ${ }^{3}$ Densely tangled woods might contain a traditional house platform, boundary-marking

3 After several tragic early epidemics, careful Catholic mission records of the population began in 1838 , and French state records began in the 1880s. In these sources, the population was recorded as being 2,141 in $1838 ; 2,400$ in $1844 ; 2,270$ in $1845 ; 1,350$ in 1860; 936 in 1871; 656 in $1880 ; 446$ in 1885; 508 in 1892; 580 in 1897; 529 in 1911; 501 in 1926; and 490 in 1936 (Vallaux 1994: 89). The population passed 600 persons for the first time in over a century in the 1990s. It was 566 in 1971; 556 in 1977; 582 in 1983; 620 in 1988; and 1,087 in 1996. In 2012, the population stood at 1,239 persons, with the expectation of continued growth (ISPF 2015a, 2015b). 
sitting stone or stonework structure of unknown utility, or one or more charming quarried stone houses, in the French provincial style, from the height of the Catholic instauration in the mid-nineteenth century, long abandoned and often forgotten, alongside the stone ruins of earlier cultural complexes. In a sense, the contemporary landscape is saturated with the past. However, encounters with the material facts of historical displacements and discontinuities are not always dependent on there being anything there. Indeed, encounters with what is not there, as in the absence of things one might otherwise expect to see, can be just as disconcerting and can lead contemporary Mangarevan landowners to ponder uncanny questions of cultural loss.

For instance, cultural site inventories taken in 2001 by the Association Richessses du Fenua (a Tahiti-based cultural association), and redone in 2002-03 by the Association Reo Culturelle Mangareva, identified a startlingly small number of significant freshwater features of the landscape. Moreover, two of the six identified features were the result of the Catholic mission's work: wells dug near mission structures on Aukena and at Rouru, the site of the first Polynesian convent on Mangareva. Meanwhile, only two sites were identified from among the named springs or places associated with fresh water. One was the Bagnoire de la Princesse, a notable bath-shaped rock feature that is said to be imbued with sacredness and reserved to the now disestablished chieftainship, and is located on the Chemin des Vierges (also called the Chemin des Soeurs), the primary walking route to the now disestablished, ruined and vaguely haunted convent site at Rouru. The other was the Poatu Okame, also close to Rouru, a 'natural' reservoir that is said to have traditionally never dried out, even in the most extreme droughts, and that was thought to have curative powers in the pre-contact era. Another site is the break in the ridgeline called Manu Ka'u, where Noe's mythical canoe pierced the island, releasing a flow of water that descended towards the marae named Te Teito, a traditional Mangarevan temple, and whose course, sometimes filled with water, can readily be found at the centre of Rikitea village. Neither survey identified any of the previously notable freshwater springs whose names were sometimes given to the adjacent villages, or that served as the sites - if not exactly the sources—of chiefly authority (Buck 1938b: 6; Mamatui n.d.a).

Curiously, disappearing springs and absent flowing waters are in conversation with what Buck (1938b) describes as a myth of the oldest human times on these islands. Mangareva, the largest of the islands, is said 
to have been first discovered by two brothers, Moa and Miru, whose exploratory voyaging brought them to a delightful, verdant and fecund land. On arrival they discovered a magical spring guarded by two spirit beings who took the desirable form of beautiful women from another world called Po and for whom the spring served as a gateway. One of the spirit women was captured and agreed to live with Moa as his wife, while the other escaped back to Po through the spring-cum-gateway. After various and somewhat violent negotiations, Moa's new wife agreed to travel back to Po, secure numerous delicious and productive foodstuffs and return them to Mangareva in order to feed her husband and his brother in perpetuity. On her return with numerous fresh plantings and cultivars, she cautioned the brothers not to overindulge their gross appetites lest some unspecified ill befall them. Being human, the brothers understandably failed to heed this warning. The result of their overconsumption was the degradation of the sweet and savoury foodstuffs, most of which became bitter, indigestible or poisonous. Moreover, the magical gateway to the other world was blocked. Mangareva and the other islands were thus cursed with a persistent scarcity of sustaining springs and foodstuffs, and Miru and Moa returned to their own land (Buck 1938b: 20-21). Though Mangareva and the other islands were eventually settled from distant 'Iva, the remarkable implication of this Mangarevan myth is that the human presence on the islands was already responsible for the loss of a golden age of watery benevolence.

Later stories recounted in Buck's Ethnology of Mangareva, and in the so-called 'native manuscripts' that he relied upon (Mamatui n.d.b; Tiripone n.d.), reinforce this sense of a persistent crisis of the waters and the cultivation systems that rely upon them. Similarly, Anderson and colleagues observe that:

The internal dynamics of Mangarevan cultural history are also likely to be of considerable interest in their own right. Hiroa's classic 'salvage ethnography' (1938) and the 19th century missionary account of Honoré Laval (1938), from which Hiroa derived much information, describe a society which displayed signs of a classic chiefly hierarchy severely challenged by resource limitations. (Anderson et al. 2003: 119)

One commentator among the members of the 1934 Bishop Museum Expedition described Mangareva as 'desolated' (St John, cited in Gregory 1934: 57), a comment that resonates with those of Buck. Buck has two passages that speak to the limited presence of water on the landscape: 
There are no permanent streams, though some stream beds contain a trickle of water, and a few springs exist. The name of the freshwater eel (tuna) occurs only in myth. Seepages on the uplands or near the coast were utilized to the fullest extent for growing taro. From the sea, the islands have a rugged, dry appearance, for the cultivable land and forest trees are confined to the lower level of land stretching back from the bays. (Buck 1938b: 4)

And:

In Mangareva there are no large permanent streams, and the large irrigation scheme of central and northern Polynesia was possible on only a small scale. Irrigated terraces were formed in narrow strips below rock outcrops or cliffs below which water seeped out. Many in the Atituiti district consisted of three or four terraces but a few feet wide. In olden times every trickle of water was utilized, and disused terraces are to be seen high up on the hillsides. Laval states that the soil in such mountain terraces had to be frequently replaced. In a cultivation examined, a spring of water issued from below a low cliff on the hillside and in the course of time had cut down a rocky water course. A channel had been cut at the source of the stream to lead the water some yards downhill to the first terrace cut out of the side of the hill with the outer edge built up with stones to form a retaining wall $($ kala $)$. The main channel was termed a tairua, which is also the general term for a stream or channel. Two smaller channels (kairaga-vai) were cut toward either end through the raised outer edge of the first terrace to lead the water down to the second terrace formed like the first. The small channels were blocked with earth or grass to flood a terrace when required, but the channels were sufficiently high above the main level to keep the terraces wet. The channels carried off the overflow. A third terrace completed the series, and a side channel carried the overflow back into the old stream bed. (ibid.: 226)

More recently, since the turn of the new millennium, Mangareva and the other Gambier Islands have been the site of extensive archaeological work that appears to confirm this understanding of a mixture of freshwater resources in the landscape (Green and Weisler 2000; Kirch et al. 2010; Conte and Kirch 2011; Anderson et al. 2003). For instance:

Rikitea offers a sheltered bay and canoe landing, along with one of the largest valleys with many freshwater springs at the base of Mt Duff that are watering a swampy alluvial basin which in historic times contained the most important zone of intensive taro (Colocasia esculenta) cultivation. (Anderson et al. 2003: 123) 
But at the same time, the island chain as a whole suffered from a deficit of dependable freshwater springs, running waters and swampy grounds (Green and Weisler 2000, 2002), notwithstanding significant average annual rainfall of approximately 2,000 mm (Vallaux 1994: 35).

There is a quite remarkable variability in the simple material fact of fresh water in this island group. Precisely established survey results conclude that there are no dependable water sources here, while simultaneously drawing attention to wet, swampy, spring-filled and irrigated lands that have supported a population of some size for more than a millennium (Kirch 2007; Kirch and Rallu 2007).

Inheriting a tradition of interpretation from Te Rangi Hiroa (Buck 1938a) and Sahlins (1958), Kirch (2007) and Conte and Kirch (2011) reinforce a sense that these islands constitute an unusual environment when compared to other high islands elsewhere in Eastern Polynesia (Conte and Kirch 2011: 253). ${ }^{4}$ Their eco-social model focuses on the centrality of human impacts on the transformation of the terrestrial environment, as exemplified by the diminishing abundance of terrestrial snails and certain bird species as markers of forest health, and points to 'increased deforestation and extinction of gastropods in the late period' (Conte and Kirch 2011:260). ${ }^{5}$

An early and long-running erosion sequence (Anderson et al. 2003) is associated with the argument in favour of a four-stage transformation of the local ecology:

- an era of native flora and fauna that preceded the first human (Polynesian) settlement

- the era of early settlement, archaeologically argued to have been reasonably dramatic in terms of environmental impacts, including the depredations of introduced mammals and the broad employment of cultivation practices in the domestication of the archipelago, leading to a massive retreat of 'forest' to high slopes and areas unsuitable or undesirable from the point of view of cultivation

4 The use of the Gambier case as the exception that proves the model's rule also has an intriguing history in other contexts, including political order and social stratification (e.g. Buck 1938a; Sahlins 1958).

5 Conte and Kirch also speculate that the decrease in indigenous bird populations, whether due to human resource use or the activities of Rattus exulans (the Polynesian rat), perhaps accelerated deforestation through nutrient depletion due to diminished enrichment from excrement. 
- the historical era, with the introduction of additional grazing animals, specifically goats and cows, which led to the final demise of 'native forests'

- the massive replanting of many upland and lowland terrains with new, generally exotic woods, and the general eradication of cows and goats from major islands (Butaud 2009; Thibault and Cibois 2011).

Interestingly, from the point of view of fresh water, vai takes on a curious figuration in these accounts of island ecological transformations, ecosocial interactions and the complex relationships between multiple species and features of the archipelago's ecology. Some attention is given to weather patterns, and occasional multi-year droughts predicted by the model, but little attention is given to the transformation of the presence of fresh water as root systems are disturbed and erosion alters the face of the landscape, or as grazing mammals trample upon shallow basins or reconfigure watercourses.

\section{The Semantics of Water}

The landscape is not the only entity under erosion in the contemporary Gambier world. Mangarevan, an Eastern Polynesian language, is also severely endangered (Charpentier and François 2015: 119-20). Attention to the lexical semantics of water may further extend a sense of the character of fresh water in the here and now. Aside from several highly technical discussions in historical linguistics (e.g. Dyen 2005), the idea of 'water' has not been thoroughly scrutinised in Austronesian linguistics and the culture-historical analyses that become possible through lexical analysis and the comparative method (Blust 2013). However, in a remarkable and recent work on the 'hydrological' lexicon in Jahai, a language of the Malay Peninsula, Burenhult (2008) provides a strong analytical framework for analysing the 'structural and semantic properties' of water at the intersection of language, culture and cognition. In Eastern Polynesian languages, including Mangarevan, several cultural distinctions are readily visible in comparative contrast with other language families.

As clearly evident in Greenhill and Clark's (2011) POLLEX data, ${ }^{6}$ water provides a wonderful example of the proximity of these closely related languages in Eastern Polynesia, as well as evidence of the

6 POLLEX is a comparative lexical database for Polynesian languages. 
remarkable success of ancestral navigators in transporting language and culture across vast oceanic spaces (Table 4.1). For speakers of the proto-language(s) of the navigating ancestors who settled these islands, and for contemporary speakers of Eastern Polynesian languages, 'water' was and is not a conceptually simple or singular 'fundamental category' (Burenhult 2008). Rather, across these cultures and languages, water is a fundamentally bifurcated category. Whereas speakers of various European languages might conceive of sea water and fresh water as two aspects of the same substance, Eastern Polynesian speakers might conceive of sea water and fresh water as two different substances.

Table 4.1 Primary lexical forms of water in Eastern Polynesia. ${ }^{1}$

\begin{tabular}{|l|l|l|l|l|l|l|}
\hline Form & Meaning & Hawaiian & Marquesan & Mangarevan & Tahitian & Tuamotuan \\
\hline Tahi & $\begin{array}{l}\text { shallow sea } \\
\text { near shore } \\
\text { or in lagoon, } \\
\text { salt water }\end{array}$ & Kai & Tai & Tai & Tai & Tai \\
\hline Wai & fresh water & Wai & Vai & Vai & Vai & Vai \\
\hline Waiho & $\begin{array}{l}\text { leave, lay } \\
\text { down, place }\end{array}$ & Waiho & Avai & Vei'o & - & Vaiho \\
\hline Wai-keli & $\begin{array}{l}\text { well, water- } \\
\text { hole }\end{array}$ & Wai-'eli & - & - & Vai-'eri & - \\
\hline Wai-rua & spirit & Wailua & - & - & Wairua & Vaerua \\
\hline Wai-marie & calm, placid & - & - & - & - & - \\
\hline Wai-mata & tears & Waimaka & Vaimata & - & - & Vai mata \\
\hline Wai-puna & $\begin{array}{l}\text { spring } \\
\text { (of water) }\end{array}$ & Wai puna & - & Vaipuna & Vaipuna & - \\
\hline Wai-tafe & stream, river & Waikahe & Vaitahe & - & Vai tahe & - \\
\hline Wai-uu & milk & Wai-uu & Vai-uu & - & Vai-uu & - \\
\hline Wai-wai & $\begin{array}{l}\text { weak, watery } \\
\text { a spring }\end{array}$ & - & - & - & - & - \\
\hline Puna & $\begin{array}{l}\text { bubble or } \\
\text { well up } \\
\text { buble or }\end{array}$ & Puna & Puna & Puna & - & Puna \\
\hline
\end{tabular}

${ }^{1}$ Blank cells indicate the absence of verified terms in the lexicons of the different languages, even where the basic lexical form makes sense to local speakers.

Source: Greenhill and Clark (2011). 
Beyond these initial paradigms of water comparable across closely related Eastern Polynesian languages, a catalogue of all terms in historical Mangarevan whose semantic field encompasses fresh water reveals further aspects of the culturing of water (Table 4.2). These include: (i) landscape features (puna, tairuavai) as fundamental categories; (ii) descriptive terms for qualities or characteristics of water(s); (iii) the moving or flowing action(s) of water; (iv) action relative to landscape features; (v) actions of fabrication relative to managing waters; (vi) actions of manipulation; and (vii) metaphorical or broadly figurative terms (e.g. lies are 'words like water').

Table 4.2 Lexical inventory of fresh water in Mangareva.

\begin{tabular}{|l|l|}
\hline Form & English Gloss \\
\hline 'Akatairua & Create a trench or watercourse. \\
\hline 'Anautama Vaikino & House for women to repose or retire to during menstruation. \\
\hline Ka'iraga Vai & Small irrigation trench within a plantation or garden. \\
\hline Karekare Vai & Movement on the surface of a water. \\
\hline Koko & $\begin{array}{l}\text { To break, said of billows and waves; an egress; issue; way out; } \\
\text { to run without overflowing or fall. }\end{array}$ \\
\hline Mi'ami'a & $\begin{array}{l}\text { Partially frizzled, inclined to be crisp, said of the hair, but also } \\
\text { of a wave or billow. }\end{array}$ \\
\hline Patito & To leap over anything; to jump a brook. \\
\hline Puna & A source, a spring; to boil; pupuna, plural of the subject. \\
\hline Punaga & Boiling. \\
\hline Punapuna & $\begin{array}{l}\text { To emerge, as a spring or fountain does; to spit or jet out, } \\
\text { as water. }\end{array}$ \\
\hline Punavai & A spring of water; a fire whose flames ascend. \\
\hline Rupou & $\begin{array}{l}\text { To drink by stooping down at a brook; to put one's lips to the } \\
\text { water in a cup. Rupoupou, plural of the action; rurupou, plural } \\
\text { of the subject. }\end{array}$ \\
\hline Ta'ega & Marks made by flowing water; the bed of a brook, etc. \\
\hline Taetavai & Water spilt or shed naturally, but not forming a brook. \\
\hline Tairua, Tairuavai & River, stream, irrigation trench, cf. ka'iraga vai. \\
\hline Tatapiga Vai & Action of bailing water out of a vessel. \\
\hline Toki-Vaitau & Abundance; affluence. \\
\hline Unuga-Vai & A drink, a beverage; the action of drinking (unu is to drink). \\
\hline Vai & Water. \\
\hline Vaiake & The Deluge. \\
\hline Vaie & Water that lies stagnant in places otherwise dried up. \\
\hline Vaie'u & Water that has been stirred up. \\
\hline Vaiea & Water that oozes out from underground. \\
\hline Vaierei & Water in a coconut (ere'i or tumuere'i are the coconut) \\
\hline & \\
\hline
\end{tabular}




\begin{tabular}{|l|l|}
\hline Form & English Gloss \\
\hline Vaieroero & $\begin{array}{l}\text { A prattler, a babbler; a preacher; to preach; to propagate } \\
\text { a doctrine, true or false. }\end{array}$ \\
\hline Vaieroeroraga & Propagation of lies. \\
\hline Vaikava & $\begin{array}{l}\text { Bitter water; alcoholic beverages; to be ungrateful, forgetful } \\
\text { of past kindness. }\end{array}$ \\
\hline Vaikavaraga & Ingratitude. \\
\hline Vaikura & Red water. \\
\hline Vaimaga & Water that has its source in the mountain. \\
\hline Vaimegeo & Vinegar. \\
\hline Vaioko & Ice. \\
\hline Vaipaoko & Fish pond, specifically used for poisoning fish. \\
\hline Vaipu & A pond. \\
\hline Vaipuna & Water that springs from among stones; a muddy source. \\
\hline Vaipuruka'a & Water from coconut butter. \\
\hline Vairega & Water tinged with a yellow colour. \\
\hline Vaitai & $\begin{array}{l}\text { A mixture of salt and fresh water; brackish water (tai is sea, } \\
\text { salt water). }\end{array}$ \\
\hline Vaitapu & Holy water. \\
\hline Vaito & Sugar; water of the sugarcane. \\
\hline Vaituragi & Water from a beneficial rainfall. \\
\hline Vaivai & Moist, humid; Semen humanum. \\
\hline
\end{tabular}

Sources: Janeau (1908); Rensch (1991); Tregear (2009).

In Mangarevan, as in closely related languages across Eastern Polynesia and Oceania, fresh water historically evidences a semantic lushness in its highly variable deployment across human contexts, whether literally or metaphorically. However, flowing water does not appear to be an ontologically robust domain in Mangarevan, ${ }^{7}$ at least when compared to English (river, stream, brook, creek, run, ditch, rivulet, and so forth) or Jahai, an Austro-Asiatic language traditionally spoken by hunter-gatherers for whom the riverine character of their landscape is among the most salient of ecological features (Burenhult 2008). Half of the terms shown in Table 4.2 may now be as obsolete or unknown to speakers under the age of 50 as the physical locations of many of the waters to which they might once have applied.

7 Cablitz (2008) identifies a smaller list of primary water-feature landscape terms in the Marquesas, with a comparable suggestion that freshwater features did not constitute a robust semantic sub-domain. 


\section{Culture History Distilled, Purified?}

Eastern Polynesian peoples are not and have never been only tagata tai ('peoples of the sea'). They have also always been tagata vai, entangled in the earliest histories of their places, ancestors and communities, reaching back to what Serge Dunis (2006) called the 'sweet and watery root times' of Polynesian cosmological and eco-social beginnings. These islands, like the much larger islands of Melanesia, with their famously numerous and sinuous rivers, deserve refreshed attention to their waters in several distinct and distinctly overlapping domains, including the material, economic, legal, political, ontological, mythological, toponymic, linguistic and eco-social. In this and the concluding section of this chapter, I prefer to emphasise the overlapping quality of these domains, drawing attention to the problems inherent in the construction of water as an object of scientific investigation.

In reflecting on the various contexts of two ethnographic anecdotes presented at the outset of this paper, expressing the concerns of youths and their elders alike about historical blockages and the possibilities of their removal, I suggest that the blocked transmissions that characterise my understanding of these anecdotes seem to resonate across different dimensions of vai-both in these islands and perhaps elsewhere in the parts of Eastern Polynesia where I have lived and that I know well.

While it is clear that some historically recorded water terms are no longer intelligible to contemporary Mangarevan speakers, and others do not mean quite the same thing even when they are, it is also clear that Mangarevan youths are not receiving all of the past culture of water even when there is little doubt of the semantic content of a term. In the cosmological, mythical or legendary domain of heightened speech genres and texts, the recession of the stories of the past into historical shadows and uncertainties mirrors the complex legacies of place names now felt to have been previously meaningful, concrete and present. The disruptions include the knowledge of irrigation systems and agricultural transformations of the terrain, as well as the identification of particular named bodies of water with specific kin groups or chiefly residences. Meanwhile, perhaps as both a symptom and cause of this epistemological and ontological murk, the legal regimes regulating water and its flow, or its nature as the subject of property rights, have a particular history dating from the era of the Mangarevan kingdoms of the Ariki Nui through the modernisation of the Code Mangarévien, the legal regimes of the French 
Protectorate, and then into the present. Finally, of course, the actual waters on a small island are not entirely dependable in quantity or quality, location, efficacy (for irrigation) or potability (for consumption).

At the same time, locally rooted persons (tagata tumu) are hardly the only persons to now display uncomfortable, ambiguous relationships to island waters and their significance in circulating, sometimes boiling, conversations about islands as ecological laboratories. In the Gambier Islands and on Mangareva, the historical and prehistoric status of water has been put to work in a potent analysis of eco-social collapse (Diamond 2005).

Having lived on these islands, I find it easy to be profoundly fascinated by the recent efflorescence of archaeological research on their environmental and cultural history, including its attentiveness to deforestation and ecological degradation. At the same time, I worry about some disquieting dimensions of the transformation of hard-won archaeological, biological and environmental knowledge into moral fable. Indeed, the circulation of a narrative (Diamond 2005) that casts a moral colour over Mangarevans' actions and agentive responsibility for ecological and social 'collapse' over the centuries since their arrival suggests a problematic directionality to ecological change. Diamond's argument that Mangarevans lacked a management culture sufficient to care sustainably for their islands displaces more odious dimensions of their broader history-notably the fact that Mangarevans were in robust possession of a highly stratified and complex Polynesian cultural practice at the time of European arrival, as well as the role of aggressive and sometimes sinister European cultural interventions in the process of ecological change, if not the literal collapse, of some aspects of the island biogeography at that juncture (see McAnany and Yoffee 2010).

I remain convinced of the need to add voice to concerns about the appropriateness or accuracy of 'collapsatory' accounts of Pacific peoples and their cultures in a sea of vibrantly Polynesian islands struggling with the post-colonial legacies of odious European imperialism, including (in the Gambier case) the long-term consequences of nuclear fallout (CESCEN 2006). I raise the spectre of these concerns because I am conscious of the possibility that attention to blocked waters and unfulfilled flows, to changes in the character of the landscape at the intersection of frothy nature and instrumental culture, risks reproducing what would be for me an unsatisfactory narrative and unwarranted historical causality- 
the reduction of historical experience or meaning to a model in which increased human impacts on the landscape deterministically yield a diminution of natural resources and, through transformative eco-social feedback loops, an increased disruption in culturally foundational human practices.

Like all historians, we configure the events of the past into causal sequences-stories-that order and simplify those events to give them new meanings. We do so because narrative is the chief literary form that tries to find meaning in an overwhelmingly crowded and disordered chronological reality. When we choose a plot to order our environmental histories, we give them a unity that neither nature nor the past possesses so clearly. (Cronon 1992: 1349)

In this celebrated account of eco-social transformation, Cronon is making a point that I take to be quite applicable to Mangareva.

With respect to the island's waters, the past does not flow into the present through some process of osmosis, as in a gradual accumulation of facts or knowledge across the membrane of time, a linear historical process that affords a reductive historical moral (e.g. Diamond 2005). Rather, the culture history moving through Mangareva's waters is also operating by means of a reverse osmosis whereby the porous membrane of time sometimes allows for a backward flow of the concrete, the known and the knowable. Under the action of the solvent of the present, the stuff of culture history - such as the names of sacred springs, their relation to cultural transmission or collective morality, or the relation of the founts of chiefly power to the liquid ties that bind a community to landscapesometimes moves from the visible and flowing back into a world that is subterranean and difficult to fathom. This happens when water sources are lost, even though the names remain, or when the language-encoded meaningfulness of water is lost, even though the waters themselves are still present. Meanwhile, recently significant levels of annual rainfall obscure the traces of putatively dry pasts, even as it is now difficult to locate the springs and irrigation channels that made life possible within those times. 


\section{Conclusion: Unflowing Present-Pasts or Past-Presents?}

At the same time as pointing to the Mangarevan experience of water as indexical of a broader array of historical signs and counter-signs, a broader concern with the slipperiness of seemingly uncontrovertible 'natural kinds' in established anthropological discourses seems to be warranted. Contextualised by anthropology's long entanglement with the human condition at the intersection of nature and culture, the recent literature in ecological, eco-social, multi-species, ontological and other collective shifts or currents in scholarly production indicate the existence of what Kuhn (1970) called anomalies in normal science. Are rivers and other fresh waters, in Pacific island contexts, anomalous scientific objects that disturb, or even violate, 'expectations that govern normal [anthropological] science' (Kuhn 1970: 53)? As Daston notes in her introduction to a very fine collection on the emergence, submersion and evaporation of objects of disciplinary inquiry:

Scientific objects may, like dark continents and invisible planets, take centuries of theoretical and empirical effort to find, or be accessible only by means of the most powerful instruments, but in their essence they are as enduring as quotidian objects (Daston 2000: 2).

Recently re-reading her introduction, I was struck by the irony of the minor premise of her observation. New scientific objects need not only be like quotidian objects, but sometimes they may simply be, for one reason or another, literally quotidian. If culture is a good example of an invisible planet - one not directly visible until scientifically dependable, credible tools are developed (Shapin 1995) — then surely anthropology is its powerful instrument, though one that can require somewhat regular recalibration. In conversation with the other papers collected here, I suggest that the natural category of 'flowing or standing fresh water' in the Gambier Islands may indeed require a modest but meaningful recalibration in disciplinary discourse, even as locally situated Mangarevan persons are grappling with the presence (or sometimes the absence) and significance of water on the landscape and in cultural conception.

While water has a delicious history in anthropological writings, it has played a curious role in our disciplinary practice and conception, oscillating 'between natural and cultural substance, its putative materiality masking the fact that its fluidity is a rhetorical effect of how we think 
about "nature" and "culture" in the first place' (Helmreich 2011: 132). Recent interest in water, including Helmreich's, seems to be motivated by an increased sense of the salience of this specific substance in nature, further contextualised by the (re-)emergence of nature itself as a fresh object of anthropological inquiry (Muru-Lanning 2007, 2009, 2010; Wagner 2010, 2013). However, the ongoing 'scientisation' of water in the social sciences, in which my work is partially embedded, is caught up in Féaux de la Croix's (2011) and Helmreich's (2011) separate observations that, in order to bring water into contemporary anthropological focus, there needs to be careful attention to (and potential skepticism about) the previous deployment of the qualities and characteristics of water in theory-for instance, as a trope of globalisation in its potent currents, flows, tides, logjams or frothy bubbles. Helmreich's (2011: 133) thoughts on the 'oceanisation' of globalisation seem to deserve particular attention by scholars of Pacific places and peoples because this trend may further displace attention to fresh water in a region so wonderfully, and sometimes so problematically, dominated by the characteristic and dynamic majesty of the ocean.

Two natural tropes appear to consistently play a role in centering Mangarevan conceptions, understandings and experiences of the threaded relationships between the past and the present. These are tumu and puna - roots and springs. The principles of rootedness and of frothy 'forth-springingness' seem to play numerous roles in both everyday conversations and the heightened talk contained in songs, chants and proverbs. The role of these highly salient metaphors can be observed in the preserved texts of the nineteenth and early twentieth centuries, as well as in contemporary talk.

To a certain extent, I suspect the centrality of these tropes in organising and articulating local understandings of individual and community relationships helps to explain some of the anxieties about lost springs and blocked waters. Leaving the tumu ('roots') of the present aside, the disappearance or movement of springs on a named and intimately felt landscape, the diversion of a watercourse for agricultural purposes and the cessation of riverine irrigation seem to bring into awareness a strong sense of a lost past, of a disconnection with honored antecedents, the result of which may be fundamentally challenging to senses of individual and collective self. 
The exploration of the material contexts of everyday human conditions, in particular the seemingly ubiquitous facets of nature domains, has been a key disciplinary turn in recent years (Escobar 1999; Ingold 2000, 2011). Such socio-spatial objects as forests, rivers, lagoons and winds have perhaps been too frequently overlooked, pre-theoretically intuited as universal terms that are automatically translatable across cultural regimes (Steinberg 2001; Helmreich 2011). Water, in all of its characters and qualities, seems as deserving of renewed attention in Eastern Polynesia as any of the other latently under-scrutinised features in anthropological attempts to make sense of others and other natures, or to make sense of the way we make sense of others and their natures. The material contexts at the intersection of nature and culture in everyday life offer clear purchase on the core anthropological project of translating the lives of others in such a way that conversations across and between them can take place. At the same time, the emergent interest in extending the anthropological project afresh to such renewing sources as rivers and springs, or to water itself, is also transparently a comment on the legacy of disciplinary traditions, the legacies of past objects of inquiry, and gaps and lacunae in earlier anthropological works that are now called vigorously into attention by serious contemporary concerns with the state of nature, with environmental degradation, or with ecological collapse and its implications for social stability and cultural transmission.

Thus, while embracing the opportunities offered by the investigation of puna vai ('springs') to think about the historical figurations of landscapes, places and peoples, I also appreciate the opportunity offered by the investigation of rivers in Oceania to think with, splash around, dive in and otherwise muddy these sinuous, fluid ethnographic objects. For these are rivers that may only flow in stories, like the springs and founts that flow on paper but appear to have moved or been lost in the landscape, or waters that do in fact flow but have lost their apparently previously mythical or culturally heightened qualities.

To return to, and conclude with, thoughts introduced at the outset of this chapter, I note that the moral colouration of the stories 'we' tell about standing or flowing waters would also be familiar in a North American or European cultural context, where environmental policy and rhetoric are not always instrumental but are also often about notions of the past and of past communities. Such stories reflect complex feelings of nostalgia and loss, or of time that somehow should have been 'ours' being made other. 


\section{Acknowledgments}

A flowing stream of gratitude is owed to the Pupu Vaka Varaga ko Nikola Mamatamoe, Bruno Schmidt and Daniel Teakarotu for the varagaraga in 2002-03, and again in 2009, that made this chapter possible. Hearty thanks also to Rai Chaze, Ena Manuireva, Lisa Ledvora, Eva-Marie Dubuisson, Robert Sullivan, Jerry Jacka and John Wagner for suggestive readings and important editorial advice. Finally, maro $i$ ake ki te 'u Mangareva for discussions, insights, makararaga and 'akaporoturaga. Maro'i 'aka'ou.

\section{References}

Anderson, A., E. Conte, P.V. Kirch and M. Weisler, 2003. 'Cultural Chronology in Mangareva (Gambier Islands), French Polynesia: Evidence from Recent Radiocarbon Dating.' Journal of the Polynesian Society 112: 119-140.

Blust, R., 2013. The Austronesian Languages. Canberra: The Australian National University, Research School of Pacific and Asian Studies (Pacific Linguistics 602).

Buck, P.H., 1938a. Vikings of the Sunrise. New York: Frederick A. Stokes Company.

— 1938b. The Ethnology of Mangareva. Honolulu: Bernice P. Bishop Museum (Bulletin 157).

Burenhult, N., 2008. 'Streams of Words: Hydrological Lexicon in Jahai.' Language Sciences 30: 182-199. doi.org/10.1016/j.langsci.2006.12.005

Burenhult, N. and S.C. Levinson, 2008. 'Language and Landscape: A CrossLinguistic Perspective.' Language Sciences 30: 135-150. doi.org/10.1016/ j.langsci.2006.12.028

Butaud, J.F., 2009. 'Les Gambier, un Archipel à la Végétation Naturelle Relicturelle et à la Flore Patrimoniale Menacée.' Bulletin de la Société des Études Océaniennes 315/316: 99-140.

Cablitz, G.H., 2008. "When "What" is "Where": A Linguistic Analysis of Landscape Terms, Place Names and Body Part Terms in Marquesan (Oceanic, French Polynesia).' Language Sciences 30: 200-226. doi.org/10.1016/j.langsci. 2006.12.004 
CESCEN (Commission d'Enquête sur les Consequences des Essays Nucléaires), 2006. Les Polynésiens et les Essays Nucléaires: Indépendance Nationale et Dépendance Polynésienne. Papeete: Assemblée de la Polynésie Francaise.

Charpentier, J.M. and A. François, 2015. Atlas Linguistique de la Polynésie Française / Linguistic Atlas of French Polynesia. Berlin and Papeete: De Gruyter and Université de la Polynésie Française. doi.org/10.1515/9783110260359

Conte, E. and P.V. Kirch, 2011. 'One Thousand Years of Human Environmental Transformation in the Gambier Islands (French Polynesia).' Terra Australis 29: 253-264.

Cronon, W., 1992. 'A Place for Stories: Nature, History, and Narrative.' Journal of American History 78: 1347-1376. doi.org/10.2307/2079346

Daston, L. (ed.), 2000. Biographies of Scientific Objects. Chicago: University of Chicago Press.

Diamond, J., 2005. Collapse: How Societies Choose to Fail or Succeed. New York: Penguin.

Dunis, S., 2006. 'Seaworthy Myths: A Tentative Interpretation of 'Atua Mata Riri, a Rapa Nui Procreation Chant.' In The Reñaca Papers: VI International Conference on Rapa Nui and the Pacific. Los Osos (CA): Easter Island Foundation.

Dyen, I., 2005. 'Some Notes on the Proto-Austronesian Words for "Water".' Oceanic Linguistics 44(1): 1-11.

Escobar, A., 1999. 'After Nature: Steps to an Anti-Essentialist Political Ecology.' Current Anthropology 40: 1-16. doi.org/10.1086/515799

Féaux de la Croix, J., 2011. 'Moving Metaphors We Live By: Water and Flow in the Social Sciences and around Hydroelectric Dams in Kyrgyzstan.' Central Asian Survey 30: 487-502. doi.org/10.1080/02634937.2011.614097

Feinberg, R., 1980. 'History and Structure: A Case of Polynesian Dualism.' Journal of Anthropological Research 36: 361-378. doi.org/10.1086/jar.36.3.3629530

Green, R.C. and M.I. Weisler, 2000. Mangarevan Archaeology: Interpretations Using New Data and 40 Year Old Excavations to Establish a Sequence from 1200 to 1900 A.D. Dunedin: University of Otago (Studies in Prehistoric Anthropology 19).

—_ 2002. 'The Mangarevan Sequence and Dating of the Geographic Expansion into Southeast Polynesia.' Asian Perspectives 41: 213-241. doi.org/10.1353/ asi.2003.0006 
Greenhill S.J. and R. Clark, 2011. 'POLLEX-Online: The Polynesian Lexicon Project Online.' Oceanic Linguistics 50: 551-559. doi.org/10.1353/ol.2011. 0014

Gregory, H.E., 1934. Report of the Director for 1933. Honolulu: Bernice P. Bishop Museum (Bulletin 133).

Hau'ofa, E., 1998. 'The Ocean in Us.' Contemporary Pacific 10: 392-410.

Helmreich, S., 2011. 'Nature/Culture/Seawater.' American Anthropologist 113: 132-144. doi.org/10.1111/j.1548-1433.2010.01311.x

—, 2014 . 'Waves: An Anthropology of Scientific Things.' HAU: Journal of Ethnographic Theory 4(3): 265-284.

Ingold, T., 2000. The Perception of the Environment: Essays on Livelihood, Dwelling and Skill. London: Routledge. doi.org/10.4324/9780203466025

__, 2011. Being Alive: Essays on Movement, Knowledge and Description. London: Routledge.

ISPF (Institut de la Statistique de la Polynésie Française), 2015a. 'Affiche Recensement 2012.' Viewed 5 August 2016 at: www.ispf.pf/docs/defaultsource/rp2012/AFFICHE_ISPF_RECENSEMENT_2012.jpg?sfvrsn=0

_ 2 2015b. 'Population sans Doubles Comptes, des Subdivisions, Communes et Communes Associées de Polynésie Française, de 1971 à 1996.' Viewed 5 August 2016 at: www.ispf.pf/bases/Recensements/Historique.aspx

Janeau, V.F., 1908. Essai de Grammaire de la Langue des Iles Gambier ou Mangaréva. Braine-le-Comte: Zech et Fils.

Kirch, P.V., 2007. 'Three Islands and an Archipelago: Reciprocal Interactions between Humans and Island Ecosystems in Polynesia.' Earth and Environmental Science Transactions of the Royal Society of Edinburgh 98: 85-99. doi.org/10.1017/S1755691007000011

Kirch, P., E. Conte, W. Sharp and C. Nickelsen, 2010. 'The Onemea Site (Taravai Island, Mangareva) and the Human Colonization of Southeastern Polynesia.' Archeology in Oceania 45: 66-79. doi.org/10.1002/j.18344453.2010.tb00081.x

Kirch, P.V. and J.L. Rallu (eds), 2007. The Growth and Collapse of Pacific Island Societies: Archaeological and Demographic Perspectives. Honolulu: University of Hawai'i Press.

Kuhn, T., 1970. The Structure of Scientific Revolutions (2nd edition). Chicago: University of Chicago Press. 
Laval, H., 1938. Mangareva: L'Histoire Ancienne d'un People Polynésien. Paris: Librairie Orientale Paul Geuther.

Levinson, S.C., 2008. 'Landscape, Seascape and the Ontology of Places on Rossel Island, Papua New Guinea.' Language Sciences 30: 256-290. doi.org/ 10.1016/j.langsci.2006.12.032

Malinowski, B., 1931. 'Culture.' In E. Seligman and A. Johnson (eds), Encyclopedia of the Social Sciences. New York: Macmillan.

_- 1992 [1948]. Magic, Science and Religion and Other Essays. Long Grove (IL): Waveland Press.

Mamatui, I., n.d.a. 'Manuscript PAC Mangareva 3.4.' Honolulu: Bernice P. Bishop Museum.

— n.d.b. 'Atonga Mangareva.' Honolulu: Bernice P. Bishop Museum (manuscript).

Mawyer, A., 2008. 'The Oceanic Drift in Polynesian Linguistics.' Language and Communication 28: 363-385. doi.org/10.1016/j.langcom.2008.01.012

—, 2014. 'Disoriented Space in the Gambier, French Polynesia.' ETHOS: Journal for the Society for Psychological Anthropology 42: 273-301.

_ 2015 . 'Wildlands, Deserted Bays, and Other "Bushy" Metaphors of Pacific Place.' In J.A. Bell, P. West and C. Filer (eds), Tropical Forests of Oceania: Anthropological Perspectives. Canberra: ANU Press (Asia-Pacific Environment Monograph 10).

McAnany, P.A. and N. Yoffee (eds), 2010. Questioning Collapse: Human Resilience, Ecological Vulnerability, and the Aftermath of Empire. Cambridge: Cambridge University Press.

Muru-Lanning, M., 2007. 'Tupuna Awa and Sustainable Resource: Knowledge Systems of the Waikato River.' MAI Review 1 Article 6. Viewed 6 June 2018 at: review.mai.ac.nz/MR/article/viewFile/30/30-30-1-PB.pdf

_ 2009. 'River Ownership: Inalienable Taonga and Impartible Tupuna Awa.' Sites: A Journal of Social Anthropology \& Cultural Studies 6(2): 32-56.

—, 2010. 'Tupuna Awa and Te Awa Tupuna: An Anthropological Study of Competing Discourses and Claims of Ownership to the Waikato River.' Auckland: University of Auckland (PhD diss.).

Rensch, K.H., 1991. Tikionario Arani-Mangareva. Canberra: Archipelago Press. 
Sahlins, M., 1958. Social Stratification in Polynesia. Seattle: University of Washington Press (American Ethnological Society Monograph 29).

Shapin, S., 1995. The Social History of Truth. Chicago: University of Chicago Press.

Steinberg, P.E., 2001. The Social Construction of the Ocean. Cambridge: Cambridge University Press.

Strang, V., 2004. The Meaning of Water. Oxford: Berg.

Thibault, J.C. and A. Cibois, 2011. 'From Early Polynesian Settlements to Present: Bird Extinctions in the Gambier Islands.' Pacific Science 66(3): 1-26.

Tiripone, n.d. 'Atonga Mangareva.' Honolulu: Bernice P. Bishop Museum (manuscript).

Tregear, E., 2009. Mangareva Dictionary: Gambier Islands (2nd edition). Tipaerui: Société des Etudes Océaniennes.

Vallaux, F., 1994. Mangareva et les Gambier. Tahiti: Etablissement Territorial d'Achats Groupes.

Wagner, J., 2010. 'Water Governance Today.' Anthropology News 51(1): 5-9. doi.org/10.1111/j.1556-3502.2010.51105.x

— (ed.), 2013. The Social Life of Water. New York: Berghahn Books. 
This text is taken from Island Rivers: Fresh Water and Place in Oceania, edited by John R. Wagner and Jerry K. Jacka, published 2018 by ANU Press, The Australian National University, Canberra, Australia.

doi.org/10.22459/IR.06.2018.04 